This item was submitted to Loughborough's Research Repository by the author.

Items in Figshare are protected by copyright, with all rights reserved, unless otherwise indicated.

\title{
The persistence of the past: memory, generational cohorts and the 'Iron
}

\section{Curtain'}

PLEASE CITE THE PUBLISHED VERSION

http://dx.doi.org/10.1017/S0960777314000228

PUBLISHER

(c) Cambridge University Press

VERSION

AM (Accepted Manuscript)

LICENCE

CC BY-NC-ND 4.0

\section{REPOSITORY RECORD}

Mihelj, Sabina. 2014. "The Persistence of the Past: Memory, Generational Cohorts and the 'iron Curtain"'. Loughborough University. https://hdl.handle.net/2134/15595. 
This item was submitted to Loughborough's Institutional Repository (https://dspace.lboro.ac.uk/) by the author and is made available under the following Creative Commons Licence conditions.

\section{creative
commons}

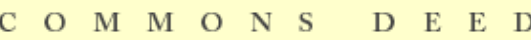

Attribution-NonCommercial-NoDerivs 2.5

You are free:

- to copy, distribute, display, and perform the work

Under the following conditions:

Attribution. You must attribute the work in the manner specified b the author or licensor.

Noncommercial. You may not use this work for commercial purposes.

No Derivative Works. You may not alter, transform, or build upon this work.

- For any reuse or distribution, you must make clear to others the license terms of this work.

- Any of these conditions can be waived if you get permission from the copyright holder.

Your fair use and other rights are in no way affected by the above.

This is a human-readable summary of the Leqal Code (the full license).

\section{Disclaimer 만}

For the full text of this licence, please go to: http://creativecommons.org/licenses/by-nc-nd/2.5/ 
Pre-print version. Final version to be published in Contemporary European History 23(3), 2014.

\section{The Persistence of the Past: Memory, Generational Cohorts and 'the Iron}

\section{Curtain'}

Sabina Mihelj

Department of Social Sciences, Loughborough University, Loughborough LE11 3TU,

UK, Email: S.Mihelj@lboro.ac.uk

The demise of state socialism in Central and Eastern Europe triggered a profound restructuring of individual and collective relationships with the past. The reshuffling of power structures swept away customary modes of thinking about communism, anticommunism and fascism, and triggered a veritable deluge of memory work. Released from the straightjacket of Cold War politics, memories of the Second World War, the communist takeover and the post-war retributions provided a rich resource for politically driven myth-making, as well as for creative engagements with the past in the visual arts and museums. ${ }^{1}$ Individual accounts of the past were drawn into this process as well. Across Central and Eastern Europe - including the Italo-Slovenian border area which constitutes the focus of attention in this article - oral historians were busy collecting personal testimonies, often with the aim of recovering marginal voices that remained suppressed under communist rule. ${ }^{2}$

The shifting contours of post-socialist memory provide plenty of evidence of the tight link between the beliefs and interests of the present and the representations of the past. Far from producing 'sincere' or 'truthful' recollections of the past, oral history initiatives gave rise to selective accounts, attuned to the specific cultural requirements and values of the post-socialist era. Former Party members used their biographies to demonstrate their personal transformation and growing support for democratization, while Catholics and anti-communists were at pains to downplay 
Pre-print version. Final version to be published in Contemporary European History 23(3), 2014.

their professional achievements under state socialism to avoid being seen as collaborators. ${ }^{3}$ Monuments commemorating the victims of communism and museums condemning the communist rule have sprung up in virtually every post-socialist country, often with direct support from newly established, fiercely anti-communist political elites. ${ }^{4}$

However, a focus on the ability of present interests to remould our perceptions of the past is only part of the story. The past is certainly, as Steinmetz puts it, 'narratively promiscuous ${ }^{, 5}$ : the very same event or experience can become incorporated into a range of distinct, even entirely incompatible recollections. Yet this is not to say that the possibilities for the remaking of the past are boundless, or down to chance and individual whims. As Schudson argues, 'there are limits to the power of actors in the present to remake the past according to their own interests', and studies of memory 'should try to understand not only how people use the past but how the past confines the uses to which people may intentionally put it' ${ }^{6}$

This article focuses on the role of generational cohorts as an anchor of continuity in memory-formation in the post-socialist context. It does not take much to show that a thorough reconfiguration of memory at mass level is contingent on generational shifts. It often takes a new generation for the new reading of history to become taken for granted or for a particularly difficult chapter in a nation's past to be reopened and scrutinized afresh. In post-war Germany, the coming of age of the first post-war generation provided the necessary social context for raising embarrassing questions about war-time collaboration, and brought a new cohort of history teachers eager to engage with the Nazi past. ${ }^{7}$ In Austria, the Waldheim affair divided the population along generational lines: a 1988 poll revealed that those over fifty were twice as likely to see Austria as a victim rather than as an accomplice of the 
Pre-print version. Final version to be published in Contemporary European History 23(3), 2014.

Anschluss. ${ }^{8}$ Likewise, in post-Franco Spain, it took a whole generation for the nation to unearth its dictatorial past, along with the mass graves dating from the Spanish Civil War. ${ }^{9}$

Despite considerable evidence of the link between generational cohorts and mnemonic persistence in other social and historical contexts, existing research on post-socialist memory tends to focus primarily on evidence of mnemonic change. In contrast, this article seeks to develop a more nuanced understanding of post-socialist memories, one capable of accounting for both mnemonic change and persistence. Methodologically, the article combines the analysis of personal memories across several generations with a reconstruction of the changing contours of everyday life in different historical periods, based on archival and secondary sources. To demonstrate the usefulness of such an approach, the article examines personal memories of life in Yugoslavia, and specifically memories of life at the Yugoslav border with Italy, as recounted by the inhabitants of the Slovenian border town of Nova Gorica in 2008.

\section{Memories between the past and the present}

Much of the classic sociological work on memory focuses on the malleability of memory, and on the ways in which memories of the past are repeatedly remoulded to suit the beliefs, interests and power struggles of the present. This 'presentist' approach was apparent already in Halbwachs' seminal work on collective memory, especially in his analysis of the changing perceptions of Jerusalem among successive generations of Jewish, Roman, Christian and Muslim pilgrims, ${ }^{10}$ and was particularly prominent in Hobsbawm and Ranger's collection of essays on the invention of tradition. $^{11}$ 
Pre-print version. Final version to be published in Contemporary European History 23(3), 2014.

Similar arguments persist in more recent literature. In his study of American public commemorations over the course of the twentieth century, Bodnar argues that the key focus of these events was not the past or its preservation, but the changing nature of power in the present. Any future commemorations will follow the same logic: 'public memory will change again as political power and social arrangements change'. ${ }^{12}$ Studies of nostalgia - including the growing literature on post-socialist nostalgia - likewise emphasize the power of the present to reshape the past. According to Berdahl, the explosion of nostalgia in the former GDR is closely tied to processes of post-socialist transition, and therefore 'tells us more about the present than the past'. ${ }^{13}$ A study of memories in post-socialist Serbia echoes this conclusion: 'Nostalgia for socialism $[\ldots]$ reveals itself as a constitutive element of the present $[\ldots]$ and is not a collection of questionable memories of an even more questionable past, which has to be reconsidered, reevaluated, and eventually overcome. ${ }^{14}$

Other authors, however, have pointed to the limits of the presentist approach and suggested that it overestimates the power of the present and fails to capture the elements of continuity in memory formation across time. Established representations of the past, claims Coser, are kept alive alongside contemporary revisions, and collective memory inevitably consists of 'partial continuity as well as new readings of the past in terms of the present'. ${ }^{15}$ Schwartz reaches a similar conclusion in his study of the changing memories of George Washington, in which he shows that with the passage of time, new images of Washington's personality and life were superimposed over older ones, but could never replace them entirely. ${ }^{16}$ Likewise, Pamela Ballinger's examination of the 'politics of the past' surrounding the Italo-Yugoslav post-World War Two territorial dispute warns against a narrowly presentist perspective on the conflict, showing how the stories told today by Italian exiles from Istria exhibit a 
Pre-print version. Final version to be published in Contemporary European History 23(3), 2014.

remarkable continuity over time. Although produced in a markedly different political environment, when both Yugoslavia and communism have long been consigned to history, their recollections of the past continue to replicate the statements made by Italian nationalist parties at the height of the border dispute over half a century ago. ${ }^{17}$ It is also worth noting that within historiographical debates, related points were raised with regard to constructivist approaches to history. For instance, in his landmark study of the production of Haitian history, Michel-Rolph Trouillot persuasively argues that the materiality of the socio-historical process inevitably sets limits for future historical narratives and that as a result, despite the irreducible gap between what happened and that which is said to have happened, 'not any fiction can pass as history'. ${ }^{18}$

Critics of the presentist approach offer a range of reasons for, and types of, the persistence of the past. Schwartz points to the constraints imposed by existing memories themselves, which act as 'frameworks of meaning' for understanding present experiences. ${ }^{19}$ In a similar fashion, Markovits and Reich argue that existing patterns of collective memory can influence a country's choice of foreign policies. ${ }^{20}$ In contrast, Schudson looks for carriers of mnemonic persistence beyond memories themselves, and identifies three: individuals with their personal memories, social vehicles such as legislation and cultural carriers such as new linguistic expressions. ${ }^{21}$ Olick and Robbins approach the persistence of the past in a somewhat different manner, identifying three different types based on the mechanisms of mnemonic continuity: instrumental persistence, which involves a conscious preservation of a particular memory to achieve present goals; cultural persistence, which stems from the cultural relevance of existing memories to new contexts; and inertial persistence, which results from the habitual reproduction of established memories. ${ }^{22}$ 
Pre-print version. Final version to be published in Contemporary European History 23(3), 2014.

General theoretical reflections on the persistence of memory only rarely explicitly engage with the role of generation, birth cohorts or age in mnemonic change and continuity, even though empirical studies repeatedly acknowledge that people of different ages, or people born at different points in time, tend to remember the same events differently. The classic explanation for the generational stratification of memory was derived from Karl Mannheim's sociology of knowledge. ${ }^{23}$ According to Mannheim, members of the same generational cohort share 'a common location in the social and historical process', which 'limits them to a specific range of potential experiences' and predisposes them 'for a characteristic mode of thought and experience'. ${ }^{24}$ Experiences gained during late adolescence and early adulthood tend to be particularly important, and exert a lasting impact throughout adult life: 'All later experiences then tend to receive their meaning from this original set, whether they appear as that set's verification or its negation and antithesis'. ${ }^{25}$ As a result, each generational cohort, although coexisting with other cohorts, will share a distinctive pattern of behaviour and outlook, rooted in experiences gained during early adulthood.

Building on Mannheim's insights as well as on other sources, a range of research conducted from a variety of disciplinary and methodological perspectives confirmed that the same applies to the generational stratification of memories. According to a sociological study based on a national sample of U.S. respondents, the vast majority of major national and international events remembered as particularly important occurred at a time when the respondents were in their late teens or early twenties. ${ }^{26}$ Similar patterns were found in a number of other large-scale studies, conducted across a range of different countries and cultural environments, and from different disciplinary perspectives. ${ }^{27}$ This is not to say that the most vivid memories 
Pre-print version. Final version to be published in Contemporary European History 23(3), 2014.

shared by generational cohorts are always linked to events experienced between the late teenage years and the early twenties. The nature of the event and its potential relevance to different generational cohorts matters as well. According to a study conducted among Russian residents, for instance, the Cuban missile crisis was most often recalled by those who were in their early thirties at the time, rather than those who were in their late teens or early twenties. ${ }^{28}$ A similar result was reached in a study of memories of the 1989 Tiananmen events among Hong Kong residents. ${ }^{29}$

Anthropological and historical studies of memory formation also provide plenty of evidence for the connection between generation and memory, and for the persistence of memory more generally. For instance, Anna Holian's study of the recollections of World War Two among the 'displaced persons' - forced labourers, concentration camp survivors, war prisoners - who found themselves in Germany at the end of the war suggests that their divergent recollections of the war, of the conflict between National Socialism and Soviet Communism, and of their own displacement, were to a large extent rooted in pre-war discourses (and many of them would became acquainted with these discourses as young adults). ${ }^{30}$ Likewise, the generational dynamics of memory is clearly evident in Loring M. Danforth and Riki Van Boeschoten's study of Greek refugee children who were evacuated from their homes at the height of the Greek Civil war in 1948 and relocated to homes elsewhere in Greece and to orphanages in Eastern Europe.$^{31}$ To capture the intertwining of mnemonic continuity and change among the different groups of refugee children, Danforth and Van Boeschoten draw an analytical distinction between 'community or experience' and 'community of memory'; while the children shared the same experiences of separation from their families, departure, migration and repatriation and hence belonged to the same 'community of experience', their transition to 
Pre-print version. Final version to be published in Contemporary European History 23(3), 2014.

adulthood and integration into diverse social groups led to the devolution of this original community into multiple 'communities of memory'. ${ }^{32}$

As this literature suggests, it is not only the selection of events that varies across generational cohorts. The way a particular event is remembered and the meanings ascribed to it can also depend substantially on formative experiences shared by particular birth cohorts. The divergent memories of World War Two examined in the already mentioned study conducted in the USA provide another case in point. While interviewees born before the war associated the war-time years primarily with their own personal experiences, people born after 1945, interpreted the meaning of the war in more general terms, focusing on its large impact and a new world structure it gave rise to - the kinds of interpretations they might have encountered in courses on American history during their adolescence. ${ }^{33}$ Similar cohort-based, distinct patterns of meanings attached to World War Two were uncovered by a comparative study of American and British collective memories. ${ }^{34}$

These arguments are of particular relevance to arguments developed in this article. They suggest that generational cohorts born during or even before socialism are less likely to accept the subsequent rewriting of memory at face value, and might instead act as 'carriers of the past' and ensure its persistence in the present. Curiously, existing research on post-socialist memories fails to consider the possible impact of generational differences, despite acknowledging that recollections of the socialist past vary significantly with the age of the interviewee. For instance, a study conducted among the Bosnian diaspora in the United States revealed markedly different perceptions of the Yugoslav president Tito; while respondents who grew up under socialism were nostalgic for the late leader and emphasized his role in creating a modern, secular Bosnian nation, interviewees born towards the end of, or after the 
Pre-print version. Final version to be published in Contemporary European History 23(3), 2014.

socialist period perceived Tito as an oppressor of Muslims. ${ }^{35}$ Similar patterns of cohort-based stratification of memory were found also in eastern Germany and in post-Soviet Russia. In both cases, memories of those educated in the socialist era differed markedly from the recollections recounted by those who completed most of their education after $1991 .{ }^{36}$ However, these cohort-based differences were interpreted from the perspective of mnemonic change rather than persistence. The positive perceptions of Tito among older Bosnians were thus seen as 'an ongoing negotiation over what it means to be Bosnian in a world without Yugoslavia' and as testimony of the 'constantly changing past'. ${ }^{37}$ Likewise, the lack of knowledge about World War Two among Russians educated after 1991 was presented as evidence of the swift dissipation of memory previously supported by the state and the state-sponsored educational system. ${ }^{38}$ The fact that the very same body of evidence could be used to demonstrate the persistence of the past (among cohorts that were born and grew up during socialism) was simply overlooked.

Generational differences also feature in another body of literature of relevance to the case study presented in this article, namely the literature on borders. The ItaloYugoslav border itself has attracted substantial scholarly attention, and some of these studies have also specifically focused on the formation of memories in the border context. Most prominently, Pamela Ballinger's study of historical memory and cultural identity around Trieste and on the Istrian peninsula notes generational differences in the accounts of experiences of Italian exiles from Istria, as well as the partial cross-generational transmission of accounts and attitudes, including ethnic stereotypes. ${ }^{39}$ In contrast, Tammy Smith's work comes closer to a presentist argument and puts more emphasis on mnemonic change; one of her contributions thus seeks to demonstrate the force of institutionally supported narratives and their ability to 
Pre-print version. Final version to be published in Contemporary European History 23(3), 2014.

influence even the memories of the most decisive events of one's life, ${ }^{40}$ while another examines the changing narrative structures of memories shared by Italian and Yugoslav Istrians who meet in New York. ${ }^{41}$

It is worth noting that the theme of continuity and discontinuity is prominent also in studies of another issue central to border studies literature, namely cultural identity. In fact, much of the existing body of work on the Italo-Yugoslav border and its fate after the fall of Yugoslavia is focused precisely on issues of identity, and more broadly on the reshaping of social and cultural ties in the region. As with the studies of borders and memory, authors tend to differ in their evaluations of continuity and change. At one end of the spectrum we find Borut Brumen's study that details the disintegration of social ties and the accelerated formation of boundaries between 'us' and 'them' on the Slovenian side of the Slovenian-Croatian border, along with the formation of new local identities paralleling the greater accentuation of national boundaries at state level. At the other end of the spectrum lies, among others, the work of Lidija Nikočević, whose research in the Croatian part of Istria suggests that local inhabitants were rather impervious to border changes and continued to defy national identifications promoted at state level, or used them instrumentally when it suited them. ${ }^{42}$ As with the research on memory, such discussions of continuity and change in the context of border identity studies may profit from a closer consideration of the impact of generational differences.

Up to this point, the term 'generation' was used rather indiscriminately and its meaning was taken for granted, partly because some of the studies quoted make little effort to define the term precisely. However, as several authors have noted, the study of what is loosely referred to as 'generations' is often plagued by conceptual confusion, and by a lack of differentiation between the effects of birth cohort, age and 
Pre-print version. Final version to be published in Contemporary European History 23(3), 2014.

life cycle. ${ }^{43}$ Much of this confusion stems from the indiscriminate use of the term 'generation', which is sometimes taken to mean a group of individuals born at the same point in time (i.e. a birth cohort), while at other points refers to age (as in references to the 'older generation' and the 'younger generation') or to a status in the context of familial and kinship relations (as in references to the 'generation of fathers' and the 'generation of sons'). Such indiscriminate use prevents us from distinguishing between the relative effects of, for instance, age and birth cohort, and acknowledging that 'because society changes, people in different cohorts age in different ways' ${ }^{44}$ Or, to offer an example of relevance to the study of generations: the prominence of positive accounts of the past among older interviewees may well have to do with the universal effects of aging rather than actual shared historical experiences. To avoid such confusion, the analysis that follows will avoid the use of the term generation, except in connection with cohort (as in 'generational cohort'). The main focus of the analysis will be on differences between birth cohorts.

\section{Sources and methods}

The analysis presented in this article is based on two major types of sources: interviews with local inhabitants of Nova Gorica on the one hand, and archival and secondary materials from local archives and libraries on the other hand. The use of archival sources compensated, at least in part, for the drawbacks of the interview sample. As pointed out in existing research on generations, an analysis based solely on a cross-sectional sample of interviews drawn from different generations at a single point in time cannot distinguish between the effects of cohorts and age, and hence further compounds the conceptual confusion mentioned earlier. ${ }^{45}$ To tackle this problem, researchers have typically resorted to longitudinal data collection, often in the form of longitudinal sets of survey data. ${ }^{46}$ 
Pre-print version. Final version to be published in Contemporary European History 23(3), 2014.

This article adopts a different solution, better suited to the small size of the sample and the qualitative nature of data collected: cohort differences revealed by interviews are interpreted in the light of archival sources and secondary historical material. ${ }^{47}$ Particular attention is paid to differences and similarities between the recollections provided by the interviewees on the one hand, and the archival and secondary evidence elucidating both the material conditions of life at the ItaloYugoslav border and the accompanying cultural narratives and discourses on the other hand. Such comparison allows us to establish whether the interviewees' perceptions of the past are rooted in historical experiences shared by a particular birth cohort, or consist of retrospective interpretations arising from the effects of aging and movement through the life-cycle, changes in the political and cultural context, and other factors.

The interview protocol consisted of two parts: the first part started with an open question, inviting the interviewee to recount the story of his or her life at the border, while the second included a list of targeted questions about specific events, starting with World War Two and ending with Slovenia's entry into the Schengen Area in 2007. Thirty-three local inhabitants were interviewed in Nova Gorica between March and June 2008, roughly a third each from the cohort born before or during the war, the cohort born between the mid-1950s and the mid-1960s, and the cohort born after 1980. The analysis presented in this article is limited to the latter two cohorts, as this suffices to illustrate the key arguments; ten interviewees born between 1921 and 1946 (three men, seven women) and nine born between 1953 and 1965 (four women, six men).

The two groups provided markedly different accounts of life at the border. For the group born before or during the war, the border featured as an impenetrable, threatening boundary, while the interviewees born between the mid-1950s and the 
Pre-print version. Final version to be published in Contemporary European History 23(3), 2014.

mid-1960s saw the vicinity of the border as an advantage, as a point of connection rather than isolation. To interpret these contrasting perceptions, we cannot rely solely on an analysis of the present and its ability to remould the past, but need to take into account the disparate historical experiences and discourses the two groups were exposed to. Put simply, the two groups built their perceptions of the border based to an important extent on their actual experiences with the border over the course of their life, and especially over the course of the formative years of early adulthood. To demonstrate this, the analysis is split into two parts, each focusing on one of the two generations. Each part starts with a reconstruction of life at the border in the period of greatest relevance to the interviewees and their memories.

A final note of clarification is in order before moving on to analysis. While this article focuses on differences between generational cohorts it is important to note that these never act in isolation from other social factors. As Eviatar Zeubavel argues, remembering is shaped within particular social environments that provide the context of our mnemonic socialization, first of all the family, but also other mnemonic communities we enter at different points in our lives, when we go to a new school, move to a new town or country, start a new job or join a local football team. ${ }^{48}$ Given that an individual's position in the social structure to a large extent determines her or his membership in particular mnemonic communities, it makes sense to expect that the choice of interpretive frames and the selection of events remembered by a particular interviewee will vary with their age, gender, educational background, and other social coordinates.

The interplay of these factors can be demonstrated by looking at the ways in which memories of life at the Italo-Yugoslav border were shaped by the public/private distinction, namely the extent to which interviewees organized their recollections 
Pre-print version. Final version to be published in Contemporary European History 23(3), 2014.

around intimate events tied to their family and everyday life, or around large-scale public events such as the Udine Agreement in 1955 and the disintegration of Yugoslavia in 1991-92. Among respondents born before or during the war, those who were paying more attention to public events were mostly better educated or came from families with a relatively high social position, which included for example a wife of a former major, and a daughter of a well-educated man with a high-level administrative position in a town near Nova Gorica. ${ }^{49}$ In contrast, those whose narratives centred on private lives and included only vague references to public events mostly completed only primary education or came from rural or working class families. ${ }^{50}$

A similar pattern can be discerned among respondents born between the mid1950s and the mid-1960s. Interviewees with university level education tended to mention a greater range of public events. However, this was not necessarily the case if the interviewee was female; of the three university-educated female interviewees from this generation, only one organized her narrative to a significant extent around such events. ${ }^{51}$ Compatible gender differences appear among interviewees who completed secondary education: male respondents mentioned at least some most recent political events such as the EU enlargement or Slovenia's entry into the Schengen area, while women with similar educational background focused almost exclusively on private experiences, and discussed political events only after being explicitly asked by the interviewer.

Taking into account such differences would doubtlessly further enrich the understanding of the dynamics of memory explored in this article. At the same time, however, it would also risk detracting from the clarity of analysis. The results 
Pre-print version. Final version to be published in Contemporary European History 23(3), 2014.

presented on the pages that follow therefore focus solely on differences between generational cohorts.

\section{The pre-war cohort: Living with the Iron Curtain}

Before 1947, Nova Gorica was no more than a suburb of Gorizia/Görz - an important provincial centre that historically profited from the vicinity of the port-city of Trieste and from railway connections with Vienna built in the late nineteenth and the early twentieth centuries, when the region was under Austrian rule. ${ }^{52}$ The period of growth ended with World War I, which left the city and the wider region devastated and coincided with the annexation to the Kingdom of Italy. The onset of fascism exacerbated inter-ethnic tensions between local Slavs and Italians, drawing the population into an endless spiral of harassment and violent retributions, which escalated during World War Two. ${ }^{53}$

These tensions continued into the post-World War Two years, and became enmeshed in the brewing Cold War confrontation between the United States and the Soviet Union. In June 1945, the disputed territory was temporarily divided in two. The northern part, including Gorizia and Trieste, fell under the jurisdiction of the Allied Military Government, while the southern part was left in the hands of the Yugoslav Army. Following protracted and increasingly strained negotiations that lasted almost two years, the 1947 Peace Treaty announced the creation of a 'Free Territory of Trieste', comprising the city of Trieste and the surrounding patch of territory. ${ }^{54}$ The rest of the disputed territory was divided up between the two neighboring states. Most of Gorizia was annexed to Italy, with only its eastern suburbs and the railway station - the part of the city that would soon be transformed into Nova Gorica - going to Yugoslavia. 
Pre-print version. Final version to be published in Contemporary European History 23(3), 2014.

Despite official celebrations of 'liberation' and 'return to the motherland', the new territorial arrangement provoked discontent in both Italy and Yugoslavia, with each side lamenting the loss of 'their' land. ${ }^{55}$. The festivities organized by the local People's Committee in Solkan, a suburb of Gorizia that became part of Yugoslavia, reflected these mixed feelings. While the speeches delivered by the representatives of the new administration were overflowing with victorious slogans about the realization of 'the years-long dream' and about the success of the 'historical struggle', ${ }^{56}$ it was impossible to ignore the presence of the new border, which cut Solkan off from its erstwhile center, deprived many inhabitants of their source of revenue, and severely disrupted existing family and friendship relations. To address these losses, the new administration started developing plans for a new town - a 'new Gorizia'. As one of the speakers in Solkan promised: 'we will build an even more beautiful and progressive Gorizia'. ${ }^{57}$ Despite such optimistic proclamations, however, the feelings of loss and dissatisfaction continued to shape the public discourse in the town for several months and years to come. As the newly established newspaper Nova Gorica proclaimed: 'We will build a New Gorizia, but we will nevertheless never give up the old one'. 58

The dissatisfaction with the territorial settlement was not the only reason for discontent at the time. All across Europe, the immediate post-war years were a time of extreme poverty, high rates of unemployment, and food scarcity. ${ }^{59}$ In the immediate post-war years, the population in many parts of Europe was kept afloat with the help of foreign aid, including the shipments of food, medical supplies, and the industrial and agricultural equipment provided by the United Nations Relief and Rehabilitation Agency (UNRRA). Yugoslavia was no exception. ${ }^{60}$ In 1947, however, the UNRRA began to be dissolved, and Yugoslavia refused to accept the US-led Marshall Plan that 
Pre-print version. Final version to be published in Contemporary European History 23(3), 2014.

was meant to replace it. For the eastern suburbs of Gorizia and the surrounding settlements, the advent of the Yugoslav administration therefore brought not only an unsatisfactory territorial settlement, but also a temporary loss of Western aid. ${ }^{61}$

Added to that was the general commotion and movement of people that had started already before 1947, but intensified with the implementation of the new border. ${ }^{62}$ The familiar neighbouring villages, towns and cities, along with family members, fiancées, friends and property, suddenly became part of a foreign, politically hostile country. Surrounded by a climate of insecurity, unsure of how the new Yugoslav regime would treat them, and lured by messages disseminated through Italian radio stations, many Italians, along with some Yugoslavs, decided to opt for Italian citizenship and flee to Italy. ${ }^{63}$ The population that remained in Yugoslavia had to learn to live with a new socio-political landscape and to adapt to a new border regime that put an end to old patterns of work-related migration, family and friendship ties. Obtaining permission to cross the border into Italy could easily take several months, with the applicant being asked to supply additional documents or even visit the office in Ljubljana to explain why the visit to Italy was necessary. ${ }^{64}$ Faced with the harsh restrictions on cross-border movement, economic hardship and scarcity of consumer goods, several inhabitants resorted to illegal border-crossing and smuggling of goods to boost their income or obtain goods not available in Yugoslavia. In the second half of 1951 alone, illegal border crossings constituted 95 per cent of all criminal acts against 'public order and peace' registered by Gorica's district court. ${ }^{65}$

These social, economic and personal upheavals all feature prominently in the recollections of interviewees alive at the time. Virtually all of their stories about the post-war years shared a marked contrast between the immediate post-war years on the one hand, and the period following the annexation to Yugoslavia on the other hand. 
Pre-print version. Final version to be published in Contemporary European History 23(3), 2014.

The pre-annexation period was typically presented as a kind of 'golden age', compared to which everything else was marked by decline. The exact aspects that made the period so exceptional varied. For some, the early post-war years were associated with the freedom of national expression and a celebratory atmosphere, dancing and signing. ${ }^{66}$ For others, the same period was associated primarily with economic recovery and an unlimited supply of employment opportunities:

Until they defined the border life was great for some. For me it was great, I worked in Gorizia and there was a huge range of opportunities for making profit, for earning. [...] For me it was great. I had a job, there was lots of work. You could earn extra if you were willing to work. ${ }^{67}$

Some interviewees, particularly those who were children at the time, also fondly remembered their encounters with the Allied Military Administration. They emphasised the kindness and generosity of the soldiers, mentioned food and gifts their received from them, and described the 'adventurous' rides on board of military jeeps, trucks, and even a small plane. ${ }^{68}$ In light of such fond memories of the post-war years, it is hardly surprising that some interviewees were genuinely confused when the interviewer referred to those years as the period of 'allied occupation'. One respondent insisted that 'we had no such occupation', ${ }^{69}$ while another explained that the term was simply inapplicable to the presence of Western Allies in the region. ${ }^{70}$

In contrast to the 'golden age' of the Allied Military Government, the arrival of Yugoslav rule was most often associated with disappointment, sudden decline, isolation and fear. At that point, argued one interviewee, 'an Iron Curtain was drawn'. ${ }^{71}$ Although the interviewees acknowledged that the border regime changed over time and gradually became more liberal, the most vivid memories were associated with the early years and the first experiences with the new territorial 
Pre-print version. Final version to be published in Contemporary European History 23(3), 2014.

division, which were uniformly negative. The reasons listed by the respondents were multiple, and included severe restrictions on movement imposed by the new border regime, disruption of ties with Gorizia, as well as shortages of food and other goods, censorship, and the hostile behaviour of Yugoslav soldiers. ${ }^{72}$ The following excerpt provides a case in point:

After the annexation to Yugoslavia and the establishment of the border life turned worse. We were used to go to old Gorizia for shopping, for everything. I used to work there as well, in old Gorizia. So everything changed. And on top of that the attitude of the state at the time, or the soldiers that were guarding the border, was bad, extremely bad. [...] There was nothing in the shops; pictures of our leaders in shop windows, but otherwise nothing. ${ }^{73}$

Also common were recollections of the 'strangeness' of life with a border, and the feeling of being isolated from the rest of the world. 'We were not even allowed to look over there, nothing was allowed ... We were more or less locked in', ${ }^{74}$ explained one interviewee, while another spoke of being 'cut off' from the rest of the world. ${ }^{75}$ Memories of extreme isolation often mingled with memories of scarcity, poverty and feelings of loss, as in the following passage:

It was bad. First of all they took Gorizia, that was one thing, and then there was such discipline, you could not even get near the border, let alone run across. We could not get any goods; we could not go over there.,76 Another frequently raised issue was the fear and resentment provoked by the Yugoslav border guards. The interviewees were talking about how they dreaded any contact with the guards, described their intrusive procedures, repeatedly complained about their rudeness, and mentioned examples of various sanctions and imprisonment 
Pre-print version. Final version to be published in Contemporary European History 23(3), 2014.

for people who were caught smuggling. ${ }^{77}$ For one respondent, the guards' behaviour was so unbearable that it made them akin to 'devils':

They did not allow us to go down-there, nor to speak ... The devil was shouting at me: 'Can't you read Slovenian, comrade?' That was because I was speaking to Ivana who had a bar down there. ... Yes, she had a bar. I was not even allowed to look at her. I was standing here, and she was standing there, you see? And you weren't allowed to speak. And Hermina was down there, and my cousin and all of our family, and they all came up to the border. They were allowed to come to the border, but we were not. The border guards were watching us through the border really sternly. Ours $^{78}$ were evil as well, I tell you. These guards were like devils! $!^{79}$

\section{The post-war cohort: The world's most open border}

While interviewees born before the war associated the Italo-Yugoslav border with isolation, loss and fear, those born in the 1950s and the 1960s provided a very different portrayal of life at the border. Much as the recollections of the pre-war cohort, however, their memories were also grounded in actual conditions of life at the border experienced over the course of their life. During the post-war decades, these conditions improved dramatically.

The first signal of changes to come was the signing of the first Udine Agreement in 1949, which opened the doors for limited trade relations with Italy, as well as brought an arrangement for those local inhabitants whose land remained on the other side of the new border. The so-called 'dual-owners' (dvolastniki) were issued special identification cards that allowed them to cross the border on a daily basis for the purpose of working their land. Many dual-owners used this opportunity 
Pre-print version. Final version to be published in Contemporary European History 23(3), 2014.

to acquire various consumer goods, which probably accounts for the much higher number of Yugoslav dual-owners crossing the border compared to Italian ones. ${ }^{80}$

Despite these developments, the tensions between Italy and Yugoslavia persisted and escalated in the autumn of 1953, when demonstrations and violent incidents spread across the region. ${ }^{81}$ A further few months of heightened diplomatic activity managed to diffuse the situation and in October of 1954, the London Memorandum was signed. The Free Territory of Trieste was dismembered and its two zones annexed to the two neighboring states. The settlement brought enough stability for the two countries to introduce further changes to the border regime. These changes, instituted with the second Udine Agreement in 1955, had a major impact on everyday life and economy in both Gorizia and Nova Gorica. Most important from the point of everyday life was the introduction of special border passes (propustnice or lasciapassare), which could be obtained by all inhabitants residing up to ten kilometres from the border. The passes were initially valid only for four months, and allowed only up to four border-crossings per month. ${ }^{82}$ Their popularity was enormous: within less than five months from the signing of the agreement, over 30,000 special border passes were issued in the area of Nova Gorica alone. By 1958, the total number of transits by Yugoslav holders reached 1,431.348 and stayed at about the same level until the early 1960s, while the number of transits by Italian holders in the same period remained between 450,000 and $550,000 .{ }^{83}$

The 1960s have seen another notable rise in the volume of transits, prompted by the amendments to the Udine agreement approved in $1962^{84}$ and the abolition of the visa regime in 1965. Over the course of the 1960s, the volume of transits was growing at a particularly fast rate on the Italian side: The number of border crossings by Italian citizens holding regular passports increased from 188.098 in 1964 to 
Pre-print version. Final version to be published in Contemporary European History 23(3), 2014.

5.306.411 in $1969,{ }^{85}$ while the total number of transits by Italian holders of propustnicallasciapassare reached 4,385.614 in $1967 .{ }^{86}$ The impact of economic reforms and increased cross-border traffic also resulted in a gradual recovery of the local economy. In the late 1950s, a new construction plan was adopted for Nova Gorica, and by the early 1960s, the development of the town finally took off. ${ }^{87}$ The pace of population growth followed the rhythms of construction: after a period of relatively slow growth during the 1950s, the 1960s and the 1970s saw the town's population quadruple in size, reaching 9633 in 1971 and 14638 in $1981 .^{88}$ The territorial arrangement was revisited again in 1975. The Osimo Agreement, signed in 1975 and implemented in 1977, provided the basis for a further enhancement of crossborder cooperation, the opening of additional border crossings and a further increase in cross-border traffic. ${ }^{89}$

Given the gradual relaxation of the border regime one should not be surprised at the rather positive memories of life at the border shared among interviewees born in the 1950s and later. Similarly to the pre-war cohort, these interviewees often mentioned the immediate post-war events, and their recollections shared several traits noted in the stories of the pre-war cohort, suggesting a measure of inter-cohort transmission of memory. For instance, the respondents were mentioning the collective euphoria and mass celebrations accompanying the end of the war, ${ }^{90}$ feelings of disappointment and injustice provoked by the new territorial arrangement, ${ }^{91}$ as well as various experiences of displacement, sudden migration and broken family ties. ${ }^{92}$ Yet at the same time, some elements that were prominently present in recollections of the pre-war cohort were now conspicuously absent or downplayed: in particular, the experiences of poverty, scarcity, oppression and the harshness of the Yugoslav border regime were either missing altogether or were mentioned only in passing. The sharp 
Pre-print version. Final version to be published in Contemporary European History 23(3), 2014.

distinctions between the Allied administration and the Yugoslav rule were blurred or disappeared altogether.

In line with the tendency to minimize the negative aspects of the Yugoslav rule, the post-war cohort described life at the border in fairly positive or at least ambiguous tones - in stark contrast to the perceptions of the pre-war cohort. The following exchange between Marija, born in 1925, and her daughter Lidija, born in 1961 - prompted by the interviewer's mention of the 'Iron Curtain' - provides a telling example of this clash of memories:

Lidija Bajd: This Iron Curtain appeared only with Slovenia's accession to the EU. This Iron Curtain did not exist here. Whom do I have to tell this? When I was travelling around the world people were always asking me: 'How was it behind the Iron Curtain?' What Iron Curtain?!

Marija Pahor: Oh, there was one, there was one there ...

Lidija Bajd (increasingly agitated): There was no Iron Curtain here. I mean, you really need to write this in large letters and in red, like this, because this was in fact the most open border [...] between Western and Eastern European countries. [...] Probably even more open than many borders in the West! $9^{93}$

Individual interviews with Marija and her daughter Lidija provide further examples of the mnemonic split between the two cohorts. While Marija associated the border with the tragic story of her cousin whose skirt got caught in the barbed wire when she tried to escape across the border to join her lover in Italy, ${ }^{94}$ Lidija saw the same border as nothing more than a harmless fence, used as a net in children's ball games. ${ }^{95}$ Other interviewees born in the 1950s and the 1960s also focused primarily on positive experiences: the relative freedom of movement brought by the introduction of special 
Pre-print version. Final version to be published in Contemporary European History 23(3), 2014.

border passes for local inhabitants, the ability to buy goods in Italy and thereby have access to a far greater range of consumer goods than average Yugoslav citizens, the opportunity to experience a different socio-political systems and interact with a different culture etc. As one interviewee put it:

From the very beginning we felt, here at the border, somewhat privileged. ... It seemed really good, in particular if we were comparing ourselves to people up there in Ljubljana, and with those who came to Italy only every now and then, while we were there four times a month at first, once every week. And then later on, it was unlimited, which was great. We could go there and back regularly. ${ }^{96}$

For the post-war cohort, the border was therefore associated with opportunities rather than obstacles, and functioned as a symbol of connection rather than isolation. The insurmountable, threatening divide that featured so prominently in the memories of the pre-war cohort was replaced with a far more permeable, 'open' border. To some extent, these notions of openness are anchored in the actual historical experiences of crossing the border, which were becoming far more common and straightforward thanks to the gradual liberalization of the border regime after 1955. Also important was the fact that for interviewees born after the war, the border was a part of normality, something they grew up with and learned to accept as given. Or, as one interviewee explained: 'as a child, I did not really feel the existence of the border; it simply felt self-evident that one had to show the border pass and so on'.97

Another important factor shaping the recollections of the border were the discourses that had their roots in the socialist period. The changes in the border regime occurring from the mid-1950s onwards were accompanied by major shifts in public discourse: the border that separated Yugoslavia from its capitalist neighbours 
Pre-print version. Final version to be published in Contemporary European History 23(3), 2014.

was increasingly referred to as 'the world's most open border'. This term, while clearly an exaggeration, ${ }^{98}$ was also at the centre of the emerging local field of border studies that began attracting the attention of both Italian and Yugoslav authors from the 1970s onwards, ${ }^{99}$ and became a part of mainstream political discourse not only on the Yugoslav, but also on the Italian side of the border. ${ }^{100}$ The following excerpt from a reportage published in the daily Novi list in 1971 provides a telling example of the new border discourse:

For many of our people, used to what are today the most open borders between the two systems - namely our borders with Italy and Austria crossing the state border is no longer an extraordinary experience. In contrast, for citizens of many other states, who are still closed off from the world, it represents a huge excitement and an unattainable dream. ${ }^{101}$

Most respondents from the post-war cohort recounted their experiences of the border by drawing on elements of this discourse, and in particular on notions of 'openness' and 'normality'. Even when acknowledging the earlier period when the border was closed, they typically moved quickly to describing subsequent changes. ${ }^{102}$ Several interviewees were also keen on comparing the relative openness of the Italo-Yugoslav border with the more impermeable borders further east. Such favourable comparisons can be seen as an instance of a broader, widespread tendency in Yugoslav public discourse from the early 1950s onwards, which consisted of emphasizing Yugoslavia's privileged position vis-à-vis the Soviet Bloc, and centred on its ability to combine socialism with cultural, economic and political openness to the capitalist West. ${ }^{103}$ One interviewee, for instance, drew a marked contrast between her experience of the Czech border and the Italo-Yugoslav border: 
Pre-print version. Final version to be published in Contemporary European History 23(3), 2014.

When I went to the Czech lands for the first time and saw that horrible regime, you see. You had to stay quiet and couldn't say anything, you see, because he was watching you as if I don't know what. You couldn't move because if you did he would do I don't know what to you. It was only then that I realized what a border really is, because here at this end you could never experience something like that. ${ }^{104}$

This is not to say that the recollections provided by interviewees from the post-war cohort were entirely devoid of negative experiences, or that they were shaped entirely by their own personal experiences and historical discourses experienced during socialism. The interviewees were aware of post-1990s discourses about socialism and life at the border, including the prominent use of notions such as the 'Iron Curtain', and were also familiar with the often traumatic memories of those born before the war. Their narratives about life at the border were therefore constructed in dialogue with these alternative memories. For instance, while presenting life at the border in a positive light, the interviewees often hastened to add that the border was not entirely open after all, especially not before their time, or mentioned the intrusive checks performed by the border guards. One interviewee from the post-war cohort, for instance, conceded that in the years before his birth, the border may have been far more closed and more alike an 'Iron Curtain', yet insisted that he never experienced that himself:

[W]hen I was a little boy [...] you did have strict border guards and policemen and they would check your car, but I would never agree this was an Iron Curtain. [...] I saw the Iron Curtain on the eastern side of Slovenia, not here. Here, actually, we were crossing the border whenever we wanted, without any problems. [...] You only had problems if you 
Pre-print version. Final version to be published in Contemporary European History 23(3), 2014.

were caught smuggling something across the border, that yes, but the traffic of people was entirely, very free; for two different systems, it was very, very liberal. ${ }^{105}$

In sum, these recollections provide evidence of both mnemonic persistence and malleability, both continuity and change. Rooted in actual historical experiences and socialist-era interpretations of life at the border, centred on the metaphor of the 'open border', these narratives of the past are also shaped by retrospective interpretations associated with the metaphor of the 'Iron Curtain', as well as by memories shared among the pre-war cohort.

\section{Closing remarks}

The patterns of memory revealed in this article confirm that the study of postsocialist memories can profit from a closer engagement with recent debates in memory studies - in particular, the critique of presentism - as well as from a consideration of the growing body of research on memory and generational cohorts. As showed in the analysis, recent recollections of life at the Italo-Yugoslav border are not shaped solely by the requirements of the post-socialist present, but are also based on actual historical experiences. Rather than focusing solely on the power of the postsocialist present to remake the socialist past, future research on post-socialist memory should therefore also pay attention to the ability of the socialist past to outlive the end of the Cold War, at the very least at the level of personal memories shared by those cohorts that grew up under socialism. Even if memories produced in the present necessarily displace and reorganize the layers of memories produced in the past, the latter do not disappear altogether, but continue to be used by those who were socialized with them. 
Pre-print version. Final version to be published in Contemporary European History 23(3), 2014.

Given how well-established the critique of presentism is in memory studies, one may wonder why it is that studies of post-socialist memory have so far proved so reluctant to question their own presentist bias. One of the reasons may lie in the legacy of the 'transition paradigm', which initially emerged as the dominant framework for the interpretation and understanding of the collapse of communism and the subsequent transformation. The end of the Cold War, went the argument, spelled the demise of communist totalitarianism and cultural isolation, and signalled the triumph of liberal democracy, individual freedom and capitalist economy. In line with this framework, it makes sense to expect that monolithic socialist memories will be swept away and reassessed in the light of new, liberal and democratic values, or in response to the introduction of capitalist economy.

It soon became clear, however, that these black-and-white formulas provide little insight into the actual processes of transformation. Many of the countries seemed unable to progress beyond the 'transitional' phase, and were plagued by corruption and low levels of political participation and public confidence. Faced with this outcome, several analysts abandoned the initial transition paradigm, and instead acknowledged the existence of multiple transformations, historical legacies and

continuities. ${ }^{106}$ It is time for researchers of post-socialist memory to do the same, abandon the initial fixation on mnemonic discontinuities and displacements, and adopt an approach that will do justice to the full complexity and ambiguities of postsocialist memory. The analysis of the cohort-based stratification of memory offers one possible venue, and a particularly fruitful one at that.

\section{Acknowledgments}

The interview materials presented in this chapter were collected in the framework of the project Border Communities: Microstudies of Everyday Life, Politics and Memory 
Pre-print version. Final version to be published in Contemporary European History 23(3), 2014.

in European Societies from 1945 to the Present, based at the Ludwig Boltzmann Institute for European History and Public Spheres, Vienna, Austria.

${ }^{1}$ Jan-Werner Müller, ed., Memory \& Power in Post-war Europe: Studies in the Presence of the Past (Cambridge: Cambridge University Press, 2002); Michal Kopecek, ed., Past in the Making: Historical Revisionism in Central Europe after 1989 (Budapest: Central European University Press, 2008); Olga Sarkisova and Peter Apor, eds., Past for the Eyes: East European Representations of Communism in Cinema and Museums after 1989 (Budapest: Central European University Press, 2008).

${ }^{2}$ For an overview of oral history initiatives in the region see James Mark, The Unfinished Revolution: Making Sense of the Communist Past in East-Central Europe (New Haven, NJ: Yale University Press 2010), xxi-xxiv. For examples of studies of personal memory in the post-socialist context see also contributions in Maria Todorova, ed., Remembering Communism: Genres of Representation (New York, NY: Social Science Research Council, 2010). Oral history and anthropological studies investigating (at least in part) the personal aspects of memory formation at the Italo-Slovenian as well as the adjacent Slovenian-Croatian border area include Borut Brumen, Sv. Peter in njegovi časi: socialni spomini, časi in identitete v istrski vasi Sv. Peter (Ljubljana: Založba /*cf., 2000); Pamela Ballinger, History in Exile: Memory and Identity at the Borders of the Balkans (Princeton: Princeton University Press, 2003); Tammy Smith, 'Narrative Boundaries and the Dynamics of Ethnic Conflict and Conciliation', Poetics, 35 (2007) 22-46; Tammy Smith, 'Remembering and Forgetting a Contentious Past: Voices from the Italo-Yugoslav Frontier', American Behavioural Scientist, 51,10 (2008), 1534-1554; Kaja Širok, Kolektivno spominjanje in kolektivna pozaba v obmejnem prostoru: Spomini na Gorico, 1943-1947 (PhD Dissertation) (Nova Gorica: Univerza v Novi Gorici, 2009); Alessandro Cattunar, 'Memorie di confine e identità plurime. Il confine italo-jugoslavo nei racconti di vita dei testimony, 1943-47', Diacronie: Studi di storia contemporanea. Dossier: Il mosaico dei confini. Le frontiere della modernità, 1 (October, 2009), available at: www.studistorici.com/2009/10/19/cattunar_memorie_di_confine.

${ }^{3}$ Mark, The Unfinished Revolution.

${ }^{4}$ Sarkisova and Apor, Past for the Eyes; Volkhard Knigge und Ulrich Mählert, eds., Kommunismus im Museum: Formern der Auseinandersetzung in Deutschland und Osrmitteleuropa (Köln: Böchlau Verlag, 2005).

${ }^{5}$ George Steinmetz, 'Reflections on the Role of Social Narratives in Working-Class Formation: Narrative Theory in the Social Sciences', Social Science History, 16, 3 (1992), 491.

${ }^{6}$ Michael Schudson, 'Lives, Laws, and Language: Commemorative vs. Non-commemorative Forms of Effective Public Memory', The Communication Review, 2, 1 (1997), 4-5.

${ }^{7}$ Daniel Levy and Julian B. Dierkes, 'Institutionalizing the Past: Shifting Memories of Nationhood in German Education and Immigration Legislation', in Jan-Werner Müller, ed., Memory \& Power in Postwar Europe: Studies in the Presence of the Past (Cambridge: Cambridge University Press, 2002), $244-$ 64. 
Pre-print version. Final version to be published in Contemporary European History 23(3), 2014.

${ }^{8}$ Tony Judt, 'The Past is Another Country: Myth and Memory in Post-war Europe', in in Jan-Werner Müller, ed., Memory \& Power in Post-war Europe: Studies in the Presence of the Past (Cambridge: Cambridge University Press, 2002), 157-83, 171.

${ }^{9}$ Carlos Jerez-Farrán and Samuel Amago, eds., Unearthing Franco's Legacy: Mass Graves and the Recovery of Historical Memory in Spain (Notre Dame, IN: University of Notre Dame Press, 2010).

${ }^{10}$ Maurice Halbwachs, On Collective Memory (Chicago, IL: The University of Chicago Press, 1992), 191-236.

${ }^{11}$ Eric Hobsbawm and Terence Ranger, eds., The Invention of Tradition (Cambridge: Cambridge University Press, 1983).

${ }^{12}$ John Bodnar, Remaking America: Public Memory, Commemoration and Patriotism in the Twentieth Century (Princeton, NJ: Princeton University Press, 1993), 252-3.

${ }^{13}$ Daphne Berdhal, ““(N)Ostalgie” for the Present: Memory, Longing, and East German Things', Ethnos, 62, 2 (1999), 192-211, 206.

${ }^{14}$ Tanja Petrović, “"When We Were Europe”: Socialist Workers in Serbia and their Nostalgic Narratives - The Case of the Cable factory Workers in Jagodina' in Todorova, ed., Remembering Communism, 127-154, 149.

${ }^{15}$ Lewis A. Coser, 'The Revival of the Sociology of Culture: The Case of Collective Memory', Sociological Forum, 7, 2 (1992), 365-373, 371.

${ }^{16}$ Barry Schwartz, 'Social Change and Collective Memory: The Democratization of George

Washington', American Sociological Review 56, 2 (1991), 221-236, 233.

${ }^{17}$ Pamela Ballinger, 'The Politics of the Past: Redefining Insecurity along the "World's Most Open Border"', in Jutta Weldes, Mark Laffey, Hugh Gusterson and Raymond Duvall, eds., Cultures of Insecurity: States, Communities, and the Production of Danger (Minneapolis: University of Minnesota Press, 1999), 84.

${ }^{18}$ Michel-Rolph Trouillot, Silencing the Past: Power and the Production of History (Boston, MA: Beacon Press), p. 29.

${ }^{19}$ Barry Schwartz, Abraham Lincoln and the Forge of American Memory (Chicago, IL: The Chicago University Press, 2000).

${ }^{20}$ Andrei S. Markovits and Simon Reich, 'The Contemporary Power of Memory: The Dilemmas for German Foreign Policy', The Communication Review, 2, 1 (1997), 89-119.

${ }^{21}$ Schudson, 'Lives, Laws, and Language', 6-10.

${ }^{22}$ Jeffrey K. Olick and Joyce Robbins, 'Social Memory Studies: From "Collective Memory” to the Historical Sociology of Mnemonic Practices', Annual Review of Sociology 24 (1998), 105-40, 129.

${ }^{23}$ Karl Mannheim, 'The Problem of Generations', in Essays on the Sociology of Knowledge (London: Routledge, 1952), 276-322.

${ }^{24}$ Ibid., 291.

${ }^{25}$ Ibid., 298.

${ }^{26}$ Howard Schuman and Jacqueline Scott, 'Generations and Collective Memories', American Sociological Review, 53, 3 (1989), 359-38. 
Pre-print version. Final version to be published in Contemporary European History 23(3), 2014.

${ }^{27}$ Sociological studies include Howard Schuman and Amy D. Corning, 'Collective Knowledge of Public Events: The Soviet Era from the Great Purge to Glasnost', American Journal of Sociology, 105, 4 (2000), 913-56; Howard Schuman and Willard L. Rodgers, 'Cohorts, Chronology, and Collective Memories', Public Opinion Quarterly, 28, 2 (2004), 217-54; M. Kent Jennings and Ning Zhang, 'Generations, Political Status, and Collective Memories in the Chinese Countryside', The Journal of Politics, 67, 4 (2005), 1164-89; Amy D. Corning, 'Emigration, Generation, and Collective Memories: The Presence of the Past for Emigrants from the Former Soviet Union', Social Psychology Quarterly, 73, 3 (2010), 223-44. Psychologists reached similar results, identifying a 'reminiscence bump' or 'peak' associated with events that occurred in early adulthood. See e.g. David C. Rubin, Tamara A. Rahhal and Leonard W. Poon, 'Things Learned in Early Adulthood are Remembered Best', Memory \& Cognition 26, 1 (1998), 3-19; Martin A. Conway, Qi Wang, Kazunori Hanyu and Shamsul Haque, 'A Cross-cultural Investigation of Autobiographical Memory: On the Universality and Cultural Variation of the Reminiscence Bump', Journal of Cross-Cultural Psychology, 36, 6 (2005), 739-49.

${ }^{28}$ Schuman and Corning, 'Collective Knowledge of Public Events'.

${ }^{29}$ Francis L. F. Lee, 'Generational Differences and in the Impact of Historical Events: The Tiananmen Square Incident in Contemporary Hong Kong Public Opinion', International Journal of Public Opinion Research, Online First, December 2011.

${ }^{30}$ Anna Holian, Between National Socialism and Soviet Communism: Displaced Persons in Postwar Germany (Ann Arbor, MI: University of Michigan Press, 2011).

${ }^{31}$ Loring M. Danforth and Riki Van Boeschoten, Children of the Greek Civil War: Refugees and the Politics of Memory (Chicago, IL: University of Chicago Press, 2012).

${ }^{32}$ Danforth and Van Boeschoten, Children of the Greek Civil War, 228.

${ }^{33}$ Schuman and Scott, 'Generations and Collective Memories', 373-4.

${ }^{34}$ Jacqueline Scott and Lilian Zac, 'Collective Memories in Britain and the United States', Public Opinion Quarterly, 75 (1993), 315-31.

${ }^{35}$ Fedja Burić, 'Dwelling on the Ruins of Socialist Yugoslavia: Being Bosnian by Remembering Tito', in Maria Todorova and Zsuzsa Gille, eds., Postcommunist Nostalgia (London and New York:

Berghahn, 2010), 227-43.

${ }^{36}$ Molly Andrews, Shaping History: Narratives of Political Change (Cambridge: Cambridge University Press, 2007), 134-40; James V. Wertsch, Voices of Collective Remembering (Cambridge: Cambridge University Press, 2002), 149-70.

${ }^{37}$ Burić, 'Dwelling on the Ruins of Socialist Yugoslavia', 241.

${ }^{38}$ Wertsch, Voices of Collective Remembering, 159.

${ }^{39}$ Ballinger, History in Exile, 153-170, 200-201.

${ }^{40}$ Smith, 'Remembering and Forgetting a Contentious Past'.

${ }^{41}$ Smith, 'Narrative Boundaries'.

${ }^{42}$ Lidija Nikočević, 'Myth, Rhetoric and Political Relations at the Istrian Border', in Thomas M. Wilson and Hastings Donnan, eds., Culture and Power at the Edges of the State: National Support and Subversion in European Border Regions (Münster: Lit Verlag, 2005), 229-53. 
Pre-print version. Final version to be published in Contemporary European History 23(3), 2014.

${ }^{43}$ E.g. Norman B. Ryder, 'The Cohort as a Concept in the Study of Social Change', American Sociological Review 60 (1965), 843-61.

${ }^{44}$ Matilda White Riley, 'On the Significance of Age in Sociology', American Sociological Review 52 (1987), 1-14, 4.

${ }^{45}$ M.W. Riley, 'Aging and Cohort Succession: Interpretations and Misinterpretation,' Public Opinion Quarterly, 37 (1973); Alan B. Spitzer, 'The Historical Problem of Generations', American Historical Review, 78 (1973), 1353-85; David I. Kertzer, 'Generation as a Sociological Problem', Annual Review of Sociology, 9 (1983), 125-49; Robert L. Miller, Researching Life Stories and Family Histories (London: Sage, 2000), 24-6.

${ }^{46}$ Spitzer, 'The Historical Problem of Generations', 1370-84.

${ }^{47}$ A similar mixed methodology - consisting of a combination of ethnographic and historical approaches - is used by Danforth and Van Boeschoten in their study of child refugees during the Greek Civil War (Danforth and Van Boeschoten, op. cit). I owe thanks to one of the anonymous reviewers for bringing this study to my attention.

${ }^{48}$ Eviatar Zerubavel, 'Social Memories: Steps to a Sociology of the Past', Qualitative Sociology, 19, 3 (1996), 286.

${ }^{49}$ E.g. interviews with Danica Zadravec, b. 1923, 26 Apr. 2008, Ljudmila Jakac, b. 1932, 8 Jun. 2008, and Janez Lavrin, b. 1928, 20 Jun. 2008.

${ }^{50}$ E.g. interviews with Zdenka Hauptman, b. 1935, 8 Jun. 2008, Ivanka Sever, b. 1926, 26 Apr. 2008, and Marija Pahor, b. 1925, 09. Feb. 2008.

${ }^{51}$ Interview with Lidija Bajd, b. 1961, 9 Feb. 2008.

${ }^{52}$ In the early $20^{\text {th }}$ century, Trieste was among the main continental ports of Europe, and the fifth largest Austrian town in terms of its financial revenue. See Marina Cattaruzza, 'Population Dynamics and Social Change in Trieste and its Hinterland, 1850-1914', in Richard Lawton and Robert W. Lee, eds., Population and Society in Western European port Cities, 1650-1939 (Liverpool: Liverpool University Press, 2002), 176-211.

${ }^{53}$ Elio Apih, Facismo e antifascismo nella Venezia Giulia (Bari: Laterza, 1966).

${ }^{54}$ Glenda Sluga, The Problem of Trieste and the Italo-Yugoslav Border (Albany: SUNY Press, 2001), 138.

${ }^{55}$ Ibid., 144.

${ }^{56}$ Pokrajinski arhiv v Novi Gorici (PANG), Series Mestna ljudska občina Solkan, Box 2, Document 572: 'Praznovanje priključitve', 16 Sept. 1947.

${ }^{57}$ Ibid.

${ }^{58}$ PANG, Series Gradnja Nove Gorice, Box 1, 'Nova Gorica', Nova Gorica, 1, 1 (1947), 1.

${ }^{59}$ Tony Judt, Postwar: A History of Europe since 1945 (London: Penguin, 2005), 13-40.

${ }^{60}$ John Lampe, Yugoslavia as History: Twice There Was a Country, $2^{\text {nd }}$ edition (Cambridge:

Cambridge University Press, 2000), 239.

${ }^{61}$ The aid resumed again soon after Yugoslavia's 1948 Cominform split with the Soviet Union. 
Pre-print version. Final version to be published in Contemporary European History 23(3), 2014.

${ }^{62}$ One of the latest estimates put the total number of those who left the territories annexed to Yugoslavia between 1941 and 1961 at 302.000. See Olinto Mileta Mattiuz, 'Gli spostamenti di popolazione nel territorio annesso alla Jugoslavia dopo la Seconda guerra mondiale. Tentativo di quantificazione demografica', in Dopoguerra di Confine - Povojni čas ob meji, eds. Tullia Catalan, Giulio Mellinato, Raoul Pupo, Marta Verginella (Trieste: Regione Autonoma Friuli-Venezia Giulia, Università di Trieste and Istituto regionale SML nel Friuli-Venezia Giulia, 2007), 687-704.

${ }^{63}$ Quantitative data indicating the ethnic composition of migrants from the region of Gorizia are not available, but data collected for the districts of Koper, Izola and Piran in northern Istria can serve as a useful guide. In the period between 1955 and 1957, a total of 10,265 inhabitants and their family members applied for Italian citizenship, of which an estimated 1,367 were Slovenian and 62 Croatian. See Jure Gombač, Esuli ali optanti? Zgodovinski primerv luči sodobne teorije (Ljubljana: Inštitut za slovensko izseljenstvo ZRC SAZU, 2005), 132.

${ }^{64}$ PANG, Series Mestna ljudska občina Solkan, Box 2, several different documents.

${ }^{65}$ PANG, Series Okrožno sodišče v Gorici, Box 16, Document Su 9/51, 3 Jan. 1952.

${ }^{66}$ Interview with Ivanka Sever, b.1926, 26 Apr. 2008. For a similar recollection of the period see also the interview with Marija Pahor, b. 1925, 09 Feb. 2008.

${ }^{67}$ Interview with Janez Lavrin, b. 1928, 20 Jun. 2008. See also the interview with Ljudmila Jakac, b.1932, 08 Jun. 2008, for a similar narrative.

${ }^{68}$ Interviews with Milan Majer, b.1946, 21 Jun. 2008, and Ljudmila Jakac, b. 1932, 08 Jun. 2008.

${ }^{69}$ Interview with Ana Ferluga, b. 1921, 08 Jun. 2008.

${ }^{70}$ Interview with Milan Majer, b.1946, 21 Jun. 2008.

${ }^{71}$ Interview with Ljudmila Jakac, b. 1932, 08 Jun. 2008.

${ }^{72}$ Interviews with DarinkaVodovnik, b. 1926, 26 Apr. 2008, Janez Lavrin, b. 1928, 20 Jun. 2008, Ivanka Sever, b. 1926, 26 Apr. 2008, and Ljudmila Jakac, b. 1932, 09 Jun. 2008.

${ }^{73}$ Interview with Janez Lavrin, b.1928. The mnemonic patterns identified above were far from unique to Nova Gorica. Oral history study conducted among elderly inhabitants elsewhere in the region produced similar results. See Olga Abram, 'Šanjel v času zavezniške vojaške uprave', Acta Histriae, 12, 2 (2004), 169-202; Vida Rožac-Darovec, 'L'attraversamento del confine nei ricordi delle donne istriane', Qualestoria, 35, 1 (2007), 35-58.

${ }^{74}$ Interview with Marija Pahor, b. 1925, 09 Feb. 2008

${ }^{75}$ Interview with Darinka Vodovnik, b. 1926, 26 Apr. 2008.

${ }^{76}$ Interviews with Ivanka Sever, 26 Apr. 2008, b. 1926 and Darinka Vodovnik, b. 1926, 26 Apr. 2008.

${ }^{77}$ Interviews with Zdenka Hauptman, b. 1934, 08 Jun. 2008, and Janez Lavrin, b. 1928, 20 Jun. 2008.

${ }^{78}$ Yugoslav border guards.

${ }^{79}$ Interview with Marija Pahor, b. 1925, 09 Feb. 2008.

${ }^{80}$ In 1955, the number of border transits by Yugoslav citizens in the region of Gorizia/Nova Gorizia alone was well over 200.000 , while the number of transits by Italian citizens in the same period amounted to less than 90.000. See Claudio Sambri, Una frontiera aperta: Indagini sui valichi italojugoslavi (Bologna: Arnaldo Forti Editore, 1970), 77 and 91. 
Pre-print version. Final version to be published in Contemporary European History 23(3), 2014.

${ }^{81}$ Giampaolo Valdevit, La Questione di Trieste 1941-1954: Politica internazionale e contesto locale (Milano: Franco Angeli, 1987), 257-63.

${ }^{82}$ Jože Šušmelj, 'Videmski sporazum', in Jože Pirjevec, Gorazd Bajc in Borut Klabjan, eds., Vojna in mir na Primorskem (Koper: Založba Annales, 2005), 307-322

${ }^{83}$ Sambri, Una frontiera aperta, 74 and 87.

${ }^{84}$ Zdravko Mlinar, Humanizacija mesta: Sociološke razsežnosti urbanizma in samoupravljanja v Novi Gorici (Maribor: Obzorja, 1983), 64.

${ }^{85}$ Sambri, Una frontiera aperta, 70 and 84.

${ }^{86}$ Based on Sambri, Una frontiera aperta, 74 and 87.

${ }^{87}$ Cvetko Nanut, 'Ob 25. obletnici najmlajšega mesta na naši zahodni meji', Srečanja, 5, 45-46 (1973), 7-14, 12.

${ }^{88}$ Based on data provided in Patricija Bukovič, 'Zgodovinski in prostorski razvoj Nove Gorice', MA Thesis, University of Ljubljana, 2008, 124.

${ }^{89}$ Viljenka Škorjanec, 'Priprave na osimska pogajanja', in Jože Pirjevec, Borut Klabjan in Gorzad Bajc, eds., Osimska meja (Koper: Založba Annales, 2006), 109-28, 69-70.

${ }^{90}$ Interviews with Vlado Brajkovič, b. 1960, 30 Jun 2008, Klara Udovič, b. 1958, 30 Jun. 2008, and Metka Ravnikar, b. 1956, 21 Jun 2008.

${ }^{91}$ Interview with VandaSimoniti, b. 1953, 08 Jun. 2008.

${ }^{92}$ Interviews with Anton Dekleva, b. 1953, 26 Apr. 2008, and Klara Udovič, b. 1958, 30 Jun. 2008.

${ }^{93}$ Interview with Lidija Bajd, b. 1961, 09 Feb. 2008.

${ }^{94}$ Interview with Marija Pahor, b. 1925, 09 Feb. 2008.

${ }^{95}$ Interview with Lidija Bajd, b. 1961, 09 Feb. 2008.

${ }^{96}$ Interview with Metka Ravnikar, b. 1956, 21 Jun. 2008.

${ }^{97}$ Ibid.

${ }^{98}$ Irena Šumi, 'Etnično razlikovanje v Sloveniji: Izbrane problematizacije', Razprave in Gradivo Revija za narodnostna vprašanja: Percepcije etničnega razlikovanja v Sloveniji, 45 (2004), 69, note 107.

${ }^{99}$ See e.g. Sambri, Una frontiera aperta ; R. Strassoldo and G. Delli Zotti, eds., Cooperation and Conflict in Bordr Areas (Milano: Franco Angeli Editore, 1982); A.M. Calamia, P. Mengozzi and N. Ronzitti, eds., I rapporti di vicinato tra Italia e Jugoslavia (Milano, Giuffrè, 1984); Vladimir Klemenčic, 'Odprta meja med Italijo in Jugoslavijo in vloga manjšin', Teorije in praksa, 11, 9/10 (1974), 928-36.

${ }^{100}$ Raoul Pupo, Confine scomparso: Saggi sulla storia dell'Adriatico Orientale del Novecento (Trieste: Instituto regionale per la storia del movimento di liberazione nel Friuli Venezia Giulia, 2007), 36-37.

${ }^{101}$ Novi list, 18 September 1971, 4.

${ }^{102}$ E.g. Interview with Anton Dekleva, b. 1953, 24 Apr. 2008.

${ }^{103}$ Sabina Mihelj, 'Negotiating Cold War Culture at the Crossroad of East and West: Uplifting the Working People, Entertaining the Masses, Cultivating the Nation', Comparative Studies in Society and History, 53, 3 (2011), 509-39, esp. 526-38. 
Pre-print version. Final version to be published in Contemporary European History 23(3), 2014.

${ }^{104}$ Interview with Lidija Bajd, b. 1961, 08 Feb. 2008. For a similar contrast with the Berlin Wall see the interview with Zoran Rakovec, b. 1965, 30 Jun. 2008.

${ }^{105}$ Interview with Zoran Rakovec, b. 1965, 30 Jun. 2008.

106 David Stark, 'From System Identity to Organizational Diversity: Analyzing Social Change in Eastern Europe', Contemporary Sociology, 21, 3 (1992), 299-304; Thomas Carothers, 'The End of the Transition Paradigm', Journal of Democracy, 13, 1 (2002), 5-21. 